\title{
Immuno-pathomechanism of liver fibrosis: targeting chemokine CCL2-mediated HIV:HCV nexus
}

\author{
AW Wahid Ansari ${ }^{1,2^{*}}$, Reinhold E Schmidt ${ }^{3}$, Esaki M Shankar ${ }^{4,5}$ and Adeeba Kamarulzaman ${ }^{1,2^{*}}$
}

\begin{abstract}
Even in the era of successful combination antiretroviral therapy (CART), co-infection of Hepatitis C virus (HCV) remains one of the leading causes of non-AIDS-related mortality and morbidity among HIV-positive individuals as a consequence of accelerated liver fibrosis and end-stage liver disease (ESLD). The perturbed liver microenvironment and induction of host pro-inflammatory mediators in response to HIV and HCV infections, play a pivotal role in orchestrating the disease pathogenesis and clinical outcomes. How these viruses communicate each other via chemokine CCL2 and exploit the liver specific cellular environment to exacerbate liver fibrosis in HIV/HCV co-infection setting is a topic of intense discussion. Herein, we provide recent views and insights on potential mechanisms of CCL2 mediated immuno-pathogenesis, and HIV-HCV cross-talk in driving liver inflammation. We believe CCL2 may potentially serve an attractive target of anti-fibrotic intervention against HIV/HCV co-infection associated co-morbidities.
\end{abstract}

Keywords: HIV/Hepatitis-C co-infection, Immuno-pathogenesis, Liver fibrosis, C-C chemokine ligand-2, Inflammation, Combination anti-retroviral therapy, Hepatic stellate cells, Viral cross-talk

\section{Introduction}

Liver fibrosis is an immuno-pathological event associated with chronic inflammation caused by liver injury and/or infection by the viruses. Uncontrolled fibrosis may progress to severe forms of the disease, such as liver cirrhosis $(\mathrm{CH})$ and hepato-cellular carcinoma (HCC). Globally, 35 million people are infected with HIV out of which 20-30\% individuals are co-infected with HCV [1]. The prevalence of co-infection is higher in some key populations especially people who inject drugs due to the shared mode of transmission [2]. Although significant achievements have been made in reducing HIV/AIDS-related mortality and morbidity through successful implementation of cART, HCV-related liver disease remains a major therapeutic challenge to those co-infected with this virus. One of the major impact of $\mathrm{HCV}$ coinfection is the persistent low $\mathrm{CD} 4^{+} \mathrm{T}$ cell counts in $\mathrm{HIV} / \mathrm{HCV}$ coinfected compared to HIV mono-infection individuals [3]. Conversely, co-infection of HIV adversely affects the

\footnotetext{
* Correspondence: awansari@um.edu.my; adeeba@ummc.edu.my

${ }^{1}$ Centre of Excellence for Research in AIDS, Faculty of Medicine, University of Malaya, Lambah Pantai 50603, Kuala Lumpur, Malaysia

${ }^{2}$ Department of Medicine, Faculty of Medicine, University of Malaya, Lambah Pantai 50603, Kuala Lumpur, Malaysia

Full list of author information is available at the end of the article
}

natural history of HCV infection by multiple ways including: rapid virus replication, accelerated fibrosis and poor response to antiretroviral therapy [3]. Although, cellular immune responses elicited against HCV spontaneously clear the virus in more than $30 \%$ of infected individuals $[4,5]$ but the majority of them fail to do so and end in chronicity.

$\mathrm{HCV}$ is a hepatotropic RNA virus that causes hepatitis, $\mathrm{CH}$ and HCC [6]. Given that HCV-specific CD8 + T cells are critical for virus control, non-specific immune response by innate effector NK cells, constituting around $30 \%$ of intrahepatic lymphocytes (IHL), too contribute to virus persistence and liver pathology [7]. However, in $\mathrm{HIV} / \mathrm{HCV}$ co-infection scenario, the systemic immune dysfunction and $\mathrm{CD} 4+\mathrm{T}$ cell depletion associated with $\mathrm{HIV}$, remains the major factor in $\mathrm{HCV}$ persistence and chronic liver inflammation. Growing body of evidence have supported accelerated liver fibrosis and organ failure in $\mathrm{HIV} / \mathrm{HCV}$ co-infected compared to HCV mono-infected individuals [8] especially in those with CD4 $\mathrm{T}$ cell count below 200 cells or at advanced stage of the HIV disease [9]. Although the cART regimen significantly restores $\mathrm{CD} 4^{+} \mathrm{T}$ cells in HIV mono-infection but the data 
are conflicting for $\mathrm{HIV} / \mathrm{HCV}$ co-infection. One study reported $\mathrm{CD}^{+} \mathrm{T}$ cell recovery following 4-years of HAART [10] while other does not $[9,11]$. Further, HCV coinfection has been shown to negatively impact $\mathrm{CD} 4^{+}$ $\mathrm{T}$ cell reconstitution following HAART [12]. Therefore, these studies suggest high mortality rate among the HCVcoinfected individuals as a consequence of severe liver disease, rather than AIDS-related illness.

CCL2, also known as monocyte chemo-attractant protein-1 (MCP-1), is a small molecular weight protein of $\mathrm{C}-\mathrm{C}$ chemokine family with strong chemotactic behaviour toward monocytes, NK cells and CD4+ T cells $[13,14]$. Many cell types including monocytes, dendritic cells, endothelial cells (EC) and epithelial cells produce CCL2 in response to a variety of microbial insults and pro-inflammatory stimuli. Apart from leukocyte recruiting properties, role in immune homeostasis and human diseases such as cancer, infection and autoimmunity is well appreciated [15-18]. The data from ours and others laboratories strongly suggest CCL2 a supporter of HIV replication and disease progression through multiple ways (see section CCL2 supports HIV replication and disease progression). However contribution to hepatitis virus triggered chronic liver inflammation and progression to fibrosis, has recently been described both in humans and murine models of hepatitis [19-21]. CCL2 and its receptor display a varied expression and are closely linked with liver disease. For example, in non-alcoholic steatohepatitis, both CCL2 and CCR2 levels are up-regulated, causing macrophage infilteration resulting in that eventually leads to inflammation, fibrosis, steatosis and accumulation in adipose tissues [22].

Fibrosis is a key event associated with liver injury triggered by virus and other inflammatory agents. It is characterized by excessive deposition of extra-cellular matrix (ECM) components including collagens, fibronectin and proteoglycan into Desse and reduced levels of tissue inhibitor of metalloproteinase (TIMP-1), an ECM removing matrix metalloproteinase (MMP) [23]. Human liver constitutes a complex cellular environment comprised of hepatocytes, hepatic stellate cells (HSC), macrophage (Kupffer cell) and T cell subsets. HSC has been considered as the major contributor of liver fibrosis by producing inflammatory mediators and substrates required for fibrogenesis $[24,25]$. In this regard, HCV infected hepatoma cell derived supernatant has been shown to trigger production of most potent pro-fibrotic molecule TGF- $\beta$ by HSC [26]. Notably, both HIV and HCV induce an array of inflammatory cytokines and chemokines to regulate pathogenesis of relevant diseases. Some of these include, cytokine TNF- $\alpha$, TGF- $\beta$ Interferons (IFNs) and ROS, and chemokine CCL2 (MCP-1), CCL3 (MIP1- $\alpha$ ), CCL4 (MIP-1ß), CCL5 (RANTES), CXCL8 (IL-8), CXCL9 (MIG), CXCL10 (IP-10) and CXCL11 (I-TAC) [22,27]. To discuss the contribution of individual molecule in hepatic fibrosis is beyond the scope of this review thus herein, we focus on one of the most relevant mediator CCL2. However a comprehensive analysis of chemokine-chemokine receptor in liver disease is described elsewhere [22].

In addition to liver-resident macrophage (Kupffer cell), human hepatic macrophages can be divided into 'classical' $\mathrm{CD} 14^{++} \mathrm{CD} 16^{-}$and 'non-classical' $\mathrm{CD} 14^{+} \mathrm{CD} 16^{+}$subsets. The later frequency found to be preferentially higher in liver fibrosis and HIV infection [28,29]. The circulating monocytes originated from the bone marrow are recruited into the liver in response to chemokines produced either by virus insult or injury. That later differentiate into functional liver macrophages as demonstrated in bone marrow and liver transplant mice models [30]. Functionally Kupffer cells are competent to sense the danger signals via TLR receptors and trigger release of inflammatory mediators including CCL2. On other hand, infiltrating monocyte-derived macrophages are found to be mostly linked to fibrosis and chronic inflammation. In this regard, experimental mouse model of fibrosis has demonstrated influx of inflammatory Ly-6C $\mathrm{C}^{\text {hi }}$ monocytes into the liver in response to CCL2 [31] and that letter differentiate to $\mathrm{Gr}^{+}$inflammatory subset, an equevalent of human $\mathrm{CD} 14^{+} \mathrm{CD} 16^{+}$cells.

\section{HIV/HCV co-infection immuno-pathogenesis}

$\mathrm{HCV}$-induced liver injury and subsequent progression to fibrosis is an immuno-pathological event governed by complex virus- host interactions [3,32]. Though HCVspecific infiltrating $\mathrm{T}$ cells are thought to be the major contributor of liver injury but in HIV co-infection setting, it is less likely that these functionally impaired cells can accelerate liver pathology. Accumulating body of evidence suggest hepatocytes and other liver cells can be infected and may serve as HIV reservoir [33-36], thus can play a regulatory role in shaping the liver specific immune responses. Interestingly, HIV and HCV can interact and reciprocally affect the natural history of each other. The potential mechanisms of HCV impact on HIV disease progression is not fully understood. One study reported activation of HIV-long-terminal repeat (LTR) promoter by $\mathrm{HCV}$ in transfected hepatocytes [37], while others observed increased risk of mortality among $\mathrm{HIV} / \mathrm{HCV}$ co-infected individuals despite successful cART administration $[9,11]$ as discussed in introduction part. On other hand, HIV can infect and/or activate liver cells via coreceptor CCR5 and CXCR4 to accelerate $\mathrm{HCV}$-induced hepatic fibrosis [36]. In addition to virus, HIV purified proteins such as TAT [38], gp160 [39] and accessory vpu [40] can contribute to hepatic fibrosis by induction of pro-fibrotic cytokine TGF- $\beta$. Further HIV TAT has also been shown to enhance $\mathrm{HCV}$ replication via chemokine CXCL-10 [41]. However, depletion of Kupffer's cell (KC) 
by HIV has been shown to profoundly affect the liver disease progression in $\mathrm{HIV} / \mathrm{HCV}$ co-infected individuals [42]. Taken together above studies suggest the reciprocal effects and consequences of viral interactions on the liver injury.

Immuno-pathology of $\mathrm{HIV} / \mathrm{HCV}$ co-infection associated liver disease is multi-factorial [43]. Several hypothesis of HIV-mediated acceleration of liver injury have been described in HIV/HCV co-infection $[44,45]$. This includes HIV-associated immune dysfunction, defective antiviral CD8+ T cells responses and reduced CD4/CD8 ratio. The perturbed cellular ratio may contribute to liver damage, as higher proportion of $\mathrm{CD} 8+\mathrm{T}$ cells are suggested relatively more fibrogenic than CD4+ T cells [46]. Another important event that may contribute to liver fibrosis is the direct activation of HSC by HIV gp120 or via pro-inflammatory mediators induced in response to infection [45,47]. Moreover, the potential mechanisms by which both the pathogens can contribute to liver damage may include, (1) HIV and $\mathrm{HCV}$-triggered production of reactive oxygen species (ROS) that signals via c-Jun $\mathrm{N}$-terminal kinase (JNK), extracellular signal-related kinase (ERK) and p38 mitogen activated protein kinase (p38MAPK) through NFkB to up-regulate TGF- $\beta$ production and decrease of matrix metaloprotease-3 (MMP3) [48,49]. (2) Stimulation of HCV-infected hepatocytes by HIV gp120 to induce HCV replication via TGF- $\beta$ [49]. (3) Induction of hepatocyte apoptosis by HIV and $\mathrm{HCV}$ to trigger pro-fibrotic activity of HSC as observed in both HIV/HBV and HIV/HCV coinfections [50-53].

\section{Impact of HIV-associated microbial translocation on liver fibrosis}

Immune activation is a hallmark of advanced HIV disease associated with chronic $\mathrm{T}$ cells activation and sustained plasma levels of pro-inflammatory cytokines. Systemic immune dysfunction and mucosal CD4+ T lymphocytes depletion from lymphoid tissues of gastrointestinal (GI) tract of HIV positive individuals are thought to be the major driving force behind this event. The mucosal permeability and subsequent microbial translocation leads to production of high levels of soluble (s) CD14, sCD163 and IL-6 by activated macrophages in response to microbial product, lipopolysaccharide (LPS) [54]. In addition to HIV, this phenomenon has also been observed in HIV/HCV and HIV/HBV co-infection, where a higher levels of plasma LPS, sCD14 were detected in coinfected than mono-infected individuals [54-56]. As liver cells are constantly exposed to gut-derived LPS via portal circulation, there is a high likelihood of $\mathrm{KC}$ and HSC activation to produce inflammatory mediators such as TNF- $\alpha$, TGF- $\beta$ and CCL2 $[25,57]$. Under such situation, $\mathrm{KC}$ has been attributed with larger role since binding of LPS to their TLR4 releases large amount of pro-fibrotic molecule TGF- $\beta$, TIMP-1 and collagen type 1 [58] to set the stage for initiation of fibrosis (Figure 1).

The association of microbial translocation and contribution of LPS to liver inflammation in $\mathrm{HIV} / \mathrm{HCV}$ coinfection setting has recently been recently appreciated [59-61]. These studies suggest LPS a key component account for rapid disease progression and organ failure. In addition to microbial products, a high quantity of innate anti-viral cytokine IFN- $\alpha$ and associated T cell activation, immensely contribute to virus replication and $\mathrm{CD} 4+\mathrm{T}$ cell death in HIV/HCV co-infected than HIV monoinfected individuals $[62,63]$. Given the occurrence of microbial translocation in both HIV-mono and HIV/HCV co-infections, strategies should be developed to reduce overt immune activation in order to contain progressive liver diseases.

\section{CCL2 supports HIV replication and disease progression}

Host chemokines induced by HIV may either support or inhibit virus replication. For example, C-C chemokine CCL3, CCL4, CCL5 and C-X-C chemokine CXCL12 $(\mathrm{SDF}-1 \alpha)$ has been described as potent inhibitors of R5 and R4 HIV strains by binding to their respective co-receptors CCR5 and CXCR4 [64-66]. Thus, early production of the above chemokines in lymph nodes can be beneficial in containing the virus spread. In this context, researcher have succeed in developing of CCR5 analogue, AOP-RANTES and antagonist Maraviroc $[67,68]$, the latter has now progressed to clinical practice. Unlike HIV inhibitory C-C family members, CCL2 is thought to support HIV replication by multiple ways [69-72] indicating a functional dichotomy within $\mathrm{C}-\mathrm{C}$ chemokine family members.

A number of clinical data including ours have shown elevated CCL2 in the serum $[70,71]$ and cerebrospinal fluid (CSF) [73] of HIV subjects that significantly correlates with plasma viral load. Further, we reported a differential CCL2 expression by HIV-infected viremic and aviremic individuals, suggesting active virus replication leads to greater CCL2 induction and thus diseases severity compared to suppressed one [70,71]. The potential mechanisms of CCL2 mediated enhanced HIV pathogenesis has been described elsewhere [72,74]. This includes, (1) the positive feed-back loop model where recruitment of HIV permissive CCR2+ monocytes/macrophages and CD4+ T cells at the site of infection for new round of replication $[70,75]$. (2) induction of co-receptor CXCR4 on resting CD4+ T cells [76]. (3) up-regulation of CXCR4 through IL-4 [77] (4) differentiation of helper T cell (Th0) cells to type-2 helper T cells (Th2) [78], a hallmark of HIV/AIDS. (5) enhancement of HIV virion release [79]. A summary of above mechanisms in conjunction with HCVcoinfection is described later in the article (Figure 2).

Evidence of CCL2 production is also observed in non-human primate (NHP) model of simian human 


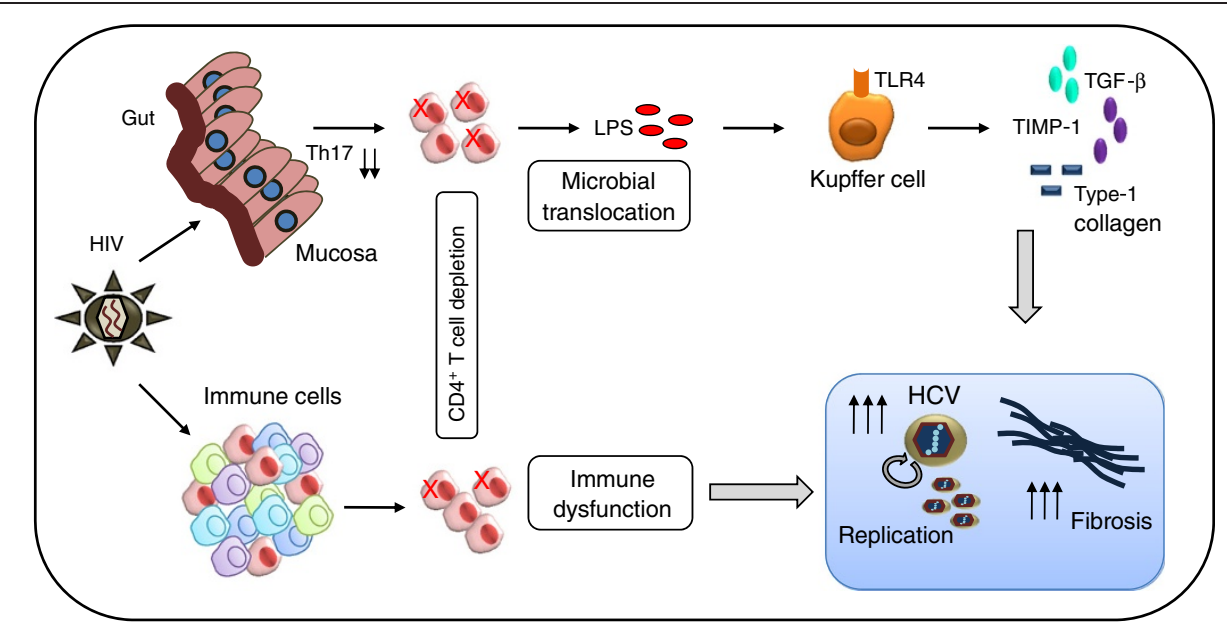

Figure 1 Adverse effects of HIV on HCV replication and liver fibrosis. HIV-associated systemic immune dysfunction and microbial translocation are the critical factors that drive HCV replication and fibrosis in HIV/HCV co-infected individuals. Depletion of CD4 ${ }^{+} T$ cells in conjunction with Th17 cells causes microbial translocation that dispenses their products in the blood circulation. Activation of Kupffer cells via TLR4 produces numerous fibrotic mediators including TGF- $\beta$, TIMP-1 and type-1 collagen. Taken together both systemic immune dysfunction and microbial translocation contribute to enhanced HCV replication and liver fibrosis.

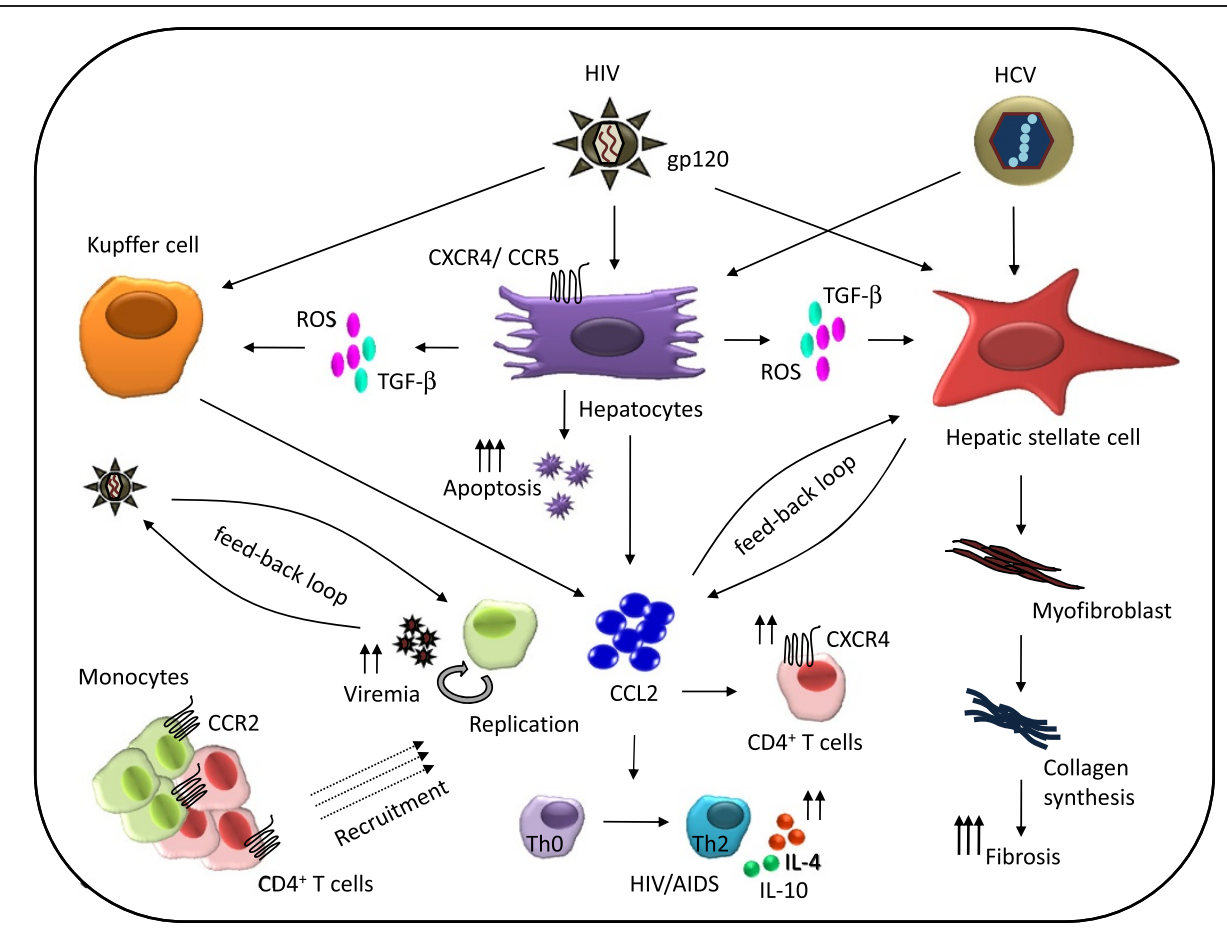

Figure 2 CCL2-mediated synergistic effects of HIV/HCV co-infection on liver fibrosis. Proposed model explains migration of HIV into the liver to infect or activate Kupffer cells, hepatocytes and HSCs directly or indirectly via ROS and TGF- $\beta$, to create CCL2 rich inflammatory milieu. CCL2 may act on HSC in a positive feed-back loop manner to accelerate fibrosis via myofibroblast and collagen synthesis. Elevated CCL2 in the liver could also recruit HIV permissive CD4 ${ }^{+} T$ cells and monocytes into the liver for next round of virus replication in a positive feed-back loop manner. This leads to persistence of a high HIV viremia. In addition, elevated CCL2 can polarize helper T cells (Th0) cells into IL-4 and IL-10 secreting Th2 phenotype, a strong determinant HIV disease progression. Further, CCL2 can induce CD4 ${ }^{+} \mathrm{T}$ cells to express higher levels of CXCR4, an HIV co-receptor. Overall this scheme depicts how a complex cellular interactions and virus cross-talks via CCL2 can potentially drive hepatic fibrosis HIV replication in HIV/HCV co-infection scenario. 
immunodeficiency virus (SHIV) infection [80], supporting the notion that CCL2 is indeed an important and relevant factor in HIV infection. Further, considering one of the most common HIV/Mtb co-infection scenario, CCL2 is believed to exacerbate the disease pathogenesis by adversely affecting the natural history of both the pathogens [81]. Although CCL2 is mostly produced by monocytes in the peripheral blood, the inflammatory $\mathrm{CD} 14^{+} \mathrm{CD} 16^{+}$ monocyte subset has been found to be the major source of CCL2 in HIV-infected individuals [29] as well as in liver fibrosis [28].

\section{CCL2 accelerates HCV-induced liver fibrosis}

A series of inflammatory mediators are up-regulated during $\mathrm{HCV}$ infection and associated liver diseases such as $\mathrm{CH}$ and HCC [82-84]. Some of these mediators are, reactive oxygen species (ROS), CCL2, IL-6, CXCL8 and CXCL10 released by activated KC and hepatocytes [46]. In addition to these, $\mathrm{HCV}$ induced early interferons (IFNs) production by $\mathrm{KC}$ triggers production of CCL2. High levels of CCL2 may recruit CCR2 ${ }^{+}$leukocytes including; monocytes, $\mathrm{NK}$ cells, $\mathrm{CD} 4^{+} \mathrm{T}$ cells into the liver to start inflammatory reactions $[85,86]$. Compelling clinical evidence suggest an increased CCL2 and its receptor CCR2 mRNA transcripts in HCV infected liver specimens $[87,88]$ that positively correlates with disease severity [89]. The relevance of CCL2 in liver diseases was further supported by studies on liver transplantation [90], HCC [91] and fibrosis regression with pharmacological inhibitor of CCL2 in mice [21]. Thus, above clinical studies and experimental models clearly suggest CCL2 a key mediator of hepatic fibrosis and their potential blocking may offer improved clinical outcome.

A detailed association between chemokines and liver diseases has been described elsewhere [22]. Some of the important chemokines and their cognate receptors relevant to $\mathrm{HCV}$ and fibrosis include, CCL2 and receptor CCR2 on monocyte/macrophages and HSC; CCL3, CCL4, CCL5 and their receptor CCR1 and CCR5 on natural killer (NK), CD8 and Th1 cells; CXCL9, CXCL10 CXCL11 and receptor CXCR3 on NK, CD8, Th1 and HSC. Further example chemokine mediated liver injury includes, persistence of elevated serum CXCL-10 and CXCL8 levels in the recipients following liver transplantation, who developed higher hepatic necro-inflammation and fibrosis [92]. Beside regulating leukocytes trafficking, CCL2 possess strong angiogenic characteristics as an inducer of VEGF expression [46] shown by infiltrating macrophages in mouse model of inflammatory associated progressive fibrosis [20]. Further, sustained levels of CCL2 has been considered critical in both triggering liver injury and subsequent development of fibrosis and thus, can serve as predictor of progression towards cirrhosis [19]. It is the cross-talk between $\mathrm{HSC}$ and $\mathrm{HCV}$-infected hepatocytes that derive immune-pathogenesis and onset of fibrosis [93] potentially via an autocrine CCL2 loop [94-97]. Apart from HCV infection of hepatocytes, viral core protein NS5A has been found to increase ROS via mitochondrial insult [98]. ROS activate KC to release CCL2 that transforms HSC to into pro-fibrogenic myofibroblast to secrete $\alpha$-smooth muscle actin and fibriller collagens I and III (Figure 2). Moreover, host genetic make-up of HCVinfected individuals can greatly influence the outcome of the liver diseases. For example, CCL2 polymorphism is found to be associated with significantly higher hepatic expression specifically in those individuals with advance liver fibrosis [99].

\section{Mechanisms of CCL2-mediated HIV:HCV interactions in liver fibrosis}

The natural infection of both HIV and HCV is affected by their presence in the same host. Compared to HCV, the effect of HIV on HCV infection is considered more deleterious (described in mechanisms of HIV/HCV immunopathogenesis section). Given that CCL2, an important factor associated with pathogenesis of both the viruses, it is important to understand the impact on liver cellular microenvironment and virus-triggered hepatic fibrosis. We herein summarize the potential mechanisms (Figure 2) that includes, (1) both HCV and HIV can induce release of CCL2 by KC, hepatocyte and HSC, either directly or indirectly via TGF- $\beta$ and ROS produced by hepatocytes $[48,49]$. (2) This up-regulates CCL2 levels in the liver to recruit that $\mathrm{CCR}_{2}{ }^{+}$monocytes and $\mathrm{CD} 4^{+} \mathrm{T}$ cells from the hepatic portal blood to the site of infection in a feed-back loop manner, resulting in rapid HIV replication and subsequent increase in viremia. (3) CCL2 can also act on HSC in a positive feed-back loop [36] to transform activated HSC into myofibroblast and collagen synthesis. In addition to their role in liver fibrosis, it is argued that high levels of CCL2 can severely affect the course of HIV infection by up-regulating HIV-co-receptor CXCR4 on $\mathrm{CD} 4^{+} \mathrm{T}$ cells [76] and polarization of helper $\mathrm{T}$ cells towards Th2 phenotype [78], a hallmark of progressive HIV disease. In summary there is complex virus-virus and host-virus interaction in HIV/HCV co-infection, and CCL2 is certainly an important factor that mediates these above cross-talks.

\section{Therapeutic management of HIV/HCV co-infection}

Significant reduction in HIV associated mortality and morbidly has been achieved with the advent of cART. However, co-infection of HCV has posed major clinical challenge as proportion of HIV/HCV co-infected individuals develop $\mathrm{CH}$ and $\mathrm{HCC}$. Generally the treatment of HCV mono-infection involves 24-48 weeks of antivirals consisting pegylated interferon-alpha (pegIFN- $\alpha$ ) plus ribavirin (RBV) [9]. A regimen that also found to be effective in cases of HIV/HCV-coinfections, achieving 
a sustained virological response (SVR) ranging between $25-50 \%$ with cure rate of $70-80 \%$ for HCV geneotype 2 and 3 and relatively reduced SVR of $18-38 \%$ for the genotype 1 and 4 infections [100]. Although, pegIFN/ RBV therapy has significantly reduced the liver associated co-morbidities in co-infected individuals, the adverse effect on central nervous system (CNS) and hepatic toxicity has led to a decline in treatment uptake as reported in EuroSIDA cohort studies [101]. Therapeutic treatment of $\mathrm{HCV} / \mathrm{HIV}$ was tremendously boosted with the advent of multiple new direct acting antivirals (DAA) including $\mathrm{HCV}$ protease and polymerase inhibitors, and $\mathrm{HCV}$ NS3-4A inhibitor telaprevir and boceprevir in 2011 [100] and the data from pilot studies demonstrated significantly improved the outcome compared to standard pegIFN/ RBV alone [102,103]. However, the drug is not in use anymore potentially due to drug-drug interaction between inhibitors of HIV and HCV, frequent adverse effect such toxicity of liver, CNS, high cost and pill burdens. Now, the European Association for the Study of the Liver (EASL) recommends a new IFN-free therapy against HIV/ HCV coinfection that includes sofosbuvir plus daclatasvir/ simprevir/ledipasvir. The newly developed AbbVie 3D regimen, consists of combination of $\mathrm{HCV}$ NS3/4A protease inhibitor ABT-450 with ritonavir, the NS5A inhibitor ombitasvir (ABT-267), and the NS5B RNA polymerase inhibitor dasabuvir (ABT-333) with or without ribavirin have shown high cure rate in phase III clinical trials, and expected to be in clinical practice very soon.

In addition to antivirals, chemokine and chemokine receptor based blockers and antagonists could provide an attaractive immuno-therapeutic approach against HIV/ HCV co-infection associated liver diseases. This startegy has proven success in HIV infection, where CCR5 antagonist, Maraviroc effectively suppress HIV replication in infected individuals [68]. Given the immune-therapeutic potentials of CCL2 blockade against breast and prostate cancer $[15,16]$, the CCL2-CCR2 target based approach may prove beneficial in reducing $\mathrm{HIV} / \mathrm{HCV}$ co-morbidities. In this regard, CCR2 antagonist, CCX140 and inhibitor BMS741672, has already been tested for Phase II studies of liver fibrosis. While, NOX-E36, a CCL2 blocker [21] and the dual CCR2/CCR5 blocker, Ceniceriviroc (Tobira Therapeutics Inc, San Francisco, CA) have shown appreciating results in rodent models of fibrosis. Given that some of the above tests in animals found to be successful, the human test is yet to prove their efficacy. Therefore, more efforts needed to understand the immune-pathological events to employ above approach to treat infection associated liver injury.

\section{Conclusion}

The majority of the literature supports the notion that mortality among $\mathrm{HIV} / \mathrm{HCV}$ co-infected individuals occurs due to liver failure rather than AIDS-related complications. Since fibrosis is an immune-pathological event it would wise to target those factors which are induced by both the viruses and are critical in liver diseases severity. CCL2 is one such pro-inflammatory molecule that could be targeted for anti-inflammatory strategies since CCL2 blockade strategy has already been implemented clinically in breast and prostate cancer immune-therapy $[15,16]$. Further understanding of intra-hepatic inflammatory network, microbial translocation and metabolic factors hold the promise for developing new therapeutic approaches. Perhaps humanized animal models supporting HIV and $\mathrm{HCV}$ infections can provide more mechanistic and therapeutic answers to this problem.

\section{Competing interests}

The authors declare that they have no competing interests.

\section{Authors' contributions}

AWA, RES, EMS and AK wrote and read the manuscript, and approved the final contents of the manuscript.

\section{Acknowledgements}

The authors acknowledge the funding supported by the University of Malaya Research Grant (RG 501-13HTM) of the Health and Translational Medicine Research Cluster to AWA and High Impact Research Grant (HIRGA E000001-20001) of the Ministry of Higher Education (MoHE) Malaysia to AK.

\section{Author details}

${ }^{1}$ Centre of Excellence for Research in AIDS, Faculty of Medicine, University of Malaya, Lambah Pantai 50603, Kuala Lumpur, Malaysia. ²Department of Medicine, Faculty of Medicine, University of Malaya, Lambah Pantai 50603, Kuala Lumpur, Malaysia. ${ }^{3}$ Department of Clinical Immunology and Rheumatology, Hannover Medical School, Carl-Neuberger Str.1, D-30625 Hannover, Germany. ${ }^{4}$ Department of Medical Microbiology, Faculty of Medicine, University of Malaya, Lambah Pantai 50603, Kuala Lumpur, Malaysia. ${ }^{5}$ Tropical Infectious Diseases Research and Education Centre, Faculty of Medicine, University of Malaya, Lambah Pantai 50603, Kuala Lumpur, Malaysia.

Received: 3 October 2014 Accepted: 24 November 2014 Published online: 10 December 2014

\section{References}

1. Rotman $Y$, Liang TJ: Coinfection with hepatitis $C$ virus and human immunodeficiency virus: virological, immunological, and clinical outcomes. J Virol 2009, 83(15):7366-7374.

2. Hernandez MD, Sherman KE: HIV/hepatitis C coinfection natural history and disease progression. Curr Opin HIV AIDS 2011, 6(6):478-482.

3. Chen JY, Feeney ER, Chung RT: HCV and HIV co-infection: mechanisms and management. Nat Rev Gastroenterol Hepatol 2014, 11(6):362-371.

4. Sulkowski MS: Hepatitis C Virus Infection in HIV-infected Patients. Curr Infect Dis Rep 2001, 3(5):469-476.

5. Singal AK, Anand BS: Management of hepatitis $C$ virus infection in HIV/HCV co-infected patients: clinical review. World J Gastroenterol 2009, 15(30):3713-3724.

6. Hernando V, Perez Cachafeiro S, Lewden C, Gonzalez J, Segura F, Oteo JA, Rubio R, Dalmau D, Moreno S, Amo JD: All-cause and liver-related mortality in HIV positive subjects compared to the general population: differences by HCV co-infection. J Hepatol 2012, 57(4):743-751.

7. Rehermann B: Pathogenesis of chronic viral hepatitis: differential roles of T cells and NK cells. Nat Med 2013, 19(7):859-868.

8. Macías J, Berenguer J, Japón MA, Girón JA, Rivero A, López-Cortés LF, Moreno A, González-Serrano M, Iribarren JA, Ortega E, Miralles P, Mira JA, Pineda JA: Fast fibrosis progression between repeated liver biopsies in patients coinfected with human immunodeficiency virus/hepatitis $C$ virus. Hepatology 2009, 50(4):1056-1063. 
9. Rockstroh JK, Mocroft A, Soriano V, Tural C, Losso MH, Horban A, Kirk O, Phillips A, Ledergerber B, Lundgren J, Euro SSG: Influence of hepatitis C virus infection on HIV-1 disease progression and response to highly active antiretroviral therapy. J Infect Dis 2005, 192:992-1002.

10. Kaufmann GR, Perrin L, Pantaleo G, Opravil M, Furrer H, Telenti A, Hirschel B, Ledergerber B, Vernazza P, Bernasconi E, Rickenbach M, Egger M, Battegay M, Swiss HIV Cohort Study Group: CD4 T-lymphocyte recovery in individuals with advanced HIV-1 infection receiving potent antiretroviral therapy for 4 years: the Swiss HIV Cohort Study. Arch Intern Med 2003, 163(18):2187-2195.

11. Miller MF, Haley C, Koziel MJ, Rowley CF: Impact of hepatitis C virus on immune restoration in HIV-infected patients who start highly active antiretroviral therapy: a meta-analysis. Clin Infect Dis Off Publ Infect Dis Soc Am 2005, 41(5):713-720.

12. Greub $G$, Ledergerber $B$, Battegay $M$, Grob $P$, Perrin $L$, Furrer $H$, Burgisser $P$, Erb P, Boggian K, Piffaretti JC, Hirschel B, Janin P, Francioli P, Flepp M, Telenti A: Clinical progression, survival, and immune recovery during antiretroviral therapy in patients with HIV-1 and hepatitis C virus coinfection: the Swiss HIV cohort study. Lancet 2000, 356(9244):1800-1805.

13. Rollins BJ: Chemokines. Blood 1997, 90(3):909-928.

14. Moser B, Loetscher P: Lymphocyte traffic control by chemokines. Nat Immunol 2001, 2(2):123-128.

15. Fridlender ZG, Buchlis G, Kapoor V, Cheng G, Sun J, Singhal S, Crisanti MC, Wang LC, Heitjan D, Snyder LA, Albelda SM: CCL2 blockade augments cancer immunotherapy. Cancer Res 2010, 70:109-118.

16. Qian BZ, Li J, Zhang H, Kitamura T, Zhang J, Campion LR, Kaiser EA, Snyder LA, Pollard JW: CCL2 recruits inflammatory monocytes to facilitate breast-tumour metastasis. Nature 2011, 475(7355):222-225.

17. Kusano KF, Nakamura K, Kusano H, Nishii N, Banba K, Ikeda T, Hashimoto K, Yamamoto M, Fujio H, Miura A, Ohta K, Morita H, Saito H, Emori T, Nakamura Y, Kusano I, Ohe T: Significance of the level of monocyte chemoattractant protein-1 in human atherosclerosis. Circ J Off J Jpn Circ Soc 2004, 68(7):671-676.

18. Suzman DL, McLaughlin M, Hu Z, Kleiner DE, Wood B, Lempicki RA, Mican JM Suffredini A, Masur H, Polis MA, Kottilil S: Identification of novel markers for liver fibrosis in HIV/hepatitis C virus coinfected individuals using genomics-based approach. AIDS 2008, 22:1433-1439.

19. Farci P, Wollenberg K, Diaz G, Engle RE, Lai ME, Klenerman P, Purcell RH, Pybus OG, Alter HJ: Profibrogenic chemokines and viral evolution predict rapid progression of hepatitis C to cirrhosis. Proc Natl Acad Sci U S A 2012, 109(36):14562-14567.

20. Ehling J, Bartneck M, Wei X, Gremse F, Fech V, Möckel D, Baeck C, Hittatiya K, Eulberg D, Luedde T, Kiessling F, Trautwein C, Lammers T, Tacke F. CCL2-dependent infiltrating macrophages promote angiogenesis in progressive liver fibrosis. Gut, 63:1960-1971

21. Baeck C, Wei X, Bartneck M, Fech V, Heymann F, Gassler N, Hittatiya K, Eulberg D, Luedde T, Trautwein C, Tacke F: Pharmacological inhibition of the chemokine $\mathrm{C}-\mathrm{C}$ motif chemokine ligand 2 (monocyte chemoattractant protein 1) accelerates liver fibrosis regression by suppressing $\mathrm{Ly}-6 \mathrm{C}(+)$ macrophage infiltration in mice. Hepatology 2014, 59:1060-1072.

22. Marra F, Tacke F: Roles for chemokines in liver disease. Gastroenterology 2014, 114:577-594e572.

23. Hernandez Gea V, Friedman SL: Pathogenesis of liver fibrosis. Annu Rev Pathol 2011, 6:425-456.

24. Marra F, Aleffi S, Galastri S, Provenzano A: Mononuclear cells in liver fibrosis. Semin Immunopathol 2009, 31(3):345-358.

25. Schwabe RF, Seki E, Brenner DA: Toll-like receptor signaling in the liver Gastroenterology 2006, 130(6):1886-1900.

26. Presser LD, McRae S, Waris G: Activation of TGF-beta1 promoter by hepatitis $C$ virus-induced AP-1 and Sp1: role of TGF-beta1 in hepatic stellate cell activation and invasion. PLoS One 2013, 8(2):e56367.

27. Huang F, Geng XP: Chemokines and hepatocellular carcinoma. World J Gastroenterol 2010, 16(15):1832-1836.

28. Zimmermann HW, Seidler S, Nattermann J, Gassler N, Hellerbrand C, Zernecke A, Tischendorf JJ, Luedde T, Weiskirchen R, Trautwein C, Tacke F: Functional contribution of elevated circulating and hepatic non-classical CD14CD16 monocytes to inflammation and human liver fibrosis. PLoS One 2010, 5:e11049.

29. Ansari AW, Meyer-Olson D, Schmidt RE: Selective expansion of pro-inflammatory chemokine CCL2-loaded CD14 + CD16+ monocytes subset in HIV-infected therapy naive individuals. J Clin Immunol 2013, 33(1):302-306.
30. Klein I, Cornejo JC, Polakos NK, John B, Wuensch SA, Topham DJ, Pierce RH, Crispe IN: Kupffer cell heterogeneity: functional properties of bone marrow derived and sessile hepatic macrophages. Blood 2007, 110(12):4077-4085.

31. Karlmark KR, Weiskirchen R, Zimmermann HW, Gassler N, Ginhoux F, Weber C, Merad M, Luedde T, Trautwein C, Tacke F: Hepatic recruitment of the inflammatory Gr1+ monocyte subset upon liver injury promotes hepatic fibrosis. Hepatology 2009, 50(1):261-274.

32. Chang CC, Crane M, Zhou J, Mina M, Post JJ, Cameron BA, Lloyd AR, Jaworowski A, French MA, Lewin SR: HIV and co-infections. Immunol Rev 2013, 254(1):114-142.

33. Cao YZ, Dieterich D, Thomas PA, Huang YX, Mirabile M, Ho DD: Identification and quantitation of HIV-1 in the liver of patients with AIDS. Aids 1992, 6(1):65-70.

34. Housset C, Boucher O, Girard PM, Leibowitch J, Saimot AG, Brechot C, Marche C: Immunohistochemical evidence for human immunodeficiency virus-1 infection of liver Kupffer cells. Hum Pathol 1990, 21(4):404-408.

35. Schmitt MP, Gendrault UL, Schweitzer C, Steffan AM, Beyer C, Royer C, Jaeck D, Pasquali JL, Kirn A, Aubertin AM: Permissivity of primary cultures of human Kupffer cells for HIV-1. AIDS Res Hum Retrovir 1990, 6(8):987-991.

36. Tuyama AC, Hong F, Saiman Y, Wang C, Ozkok D, Mosoian A, Chen P, Chen BK, Klotman ME, Bansal MB: Human immunodeficiency virus (HIV)-1 infects human hepatic stellate cells and promotes collagen I and monocyte chemoattractant protein-1 expression: implications for the pathogenesis of HIV/hepatitis C virus-induced liver fibrosis. Hepatology 2010, 52(2):612-622

37. Sengupta S, Powell E, Kong L, Blackard JT: Effects of HCV on basal and tat-induced HIV LTR activation. PLoS One 2013, 8(6):e64956.

38. Gibellini D, Zauli G, Re MC, Milani D, Furlini G, Caramelli E, Capitani S, La Placa M: Recombinant human immunodeficiency virus type-1 (HIV-1) Tat protein sequentially up-regulates IL-6 and TGF-beta 1 mRNA expression and protein synthesis in peripheral blood monocytes. Br J Haematol 1994, 88(2):261-267.

39. Hu R, Oyaizu N, Than S, Kalyanaraman VS, Wang XP, Pahwa S: HIV-1 gp160 induces transforming growth factor-beta production in human PBMC. Clin Immunol Immunopathol 1996, 80(3 Pt 1):283-289.

40. Patel P, Khan N, Rani M, Gupta D, Jameel S: The expression of HIV-1 $\mathrm{Vpu}$ in monocytes causes increased secretion of TGF-beta that activates profibrogenic genes in hepatic stellate cells. PLoS One 2014, 9(2):e88934.

41. Qu J, Zhang Q, Li Y, Liu W, Chen L, Zhu Y, Wu J: The Tat protein of human immunodeficiency virus-1 enhances hepatitis $C$ virus replication through interferon gamma-inducible protein-10. BMC Immunol 2012, 13:15.

42. Balagopal A, Ray SC, De Oca RM, Sutcliffe CG, Vivekanandan P, Higgins Y, Mehta SH, Moore RD, Sulkowski MS, Thomas DL, Torbenson MS: Kupffer cells are depleted with HIV immunodeficiency and partially recovered with antiretroviral immune reconstitution. AIDS 2009, 23:2397-2404.

43. Koziel MJ, Peters MG: Viral hepatitis in HIV infection. N Engl J Med 2007, 356(14):1445-1454.

44. Joshi D, O'Grady J, Dieterich D, Gazzard B, Agarwal K: Increasing burden of liver disease in patients with HIV infection. Lancet 2011 377(9772):1198-1209.

45. Lin W, Weinberg EM, Chung RT: Pathogenesis of accelerated fibrosis in HIV/HCV co-infection. J Infect Dis 2013, 207(Suppl 1):S13-S18.

46. Friedman SL: Mechanisms of hepatic fibrogenesis. Gastroenterology 2008, 134(6):1655-1669.

47. Bruno R, Galastri S, Sacchi P, Cima S, Caligiuri A, DeFranco R, Milani S, Gessani S, Fantuzzi L, Liotta F, Frosali F, Antonucci G, Pinzani M, Marra F: gp120 modulates the biology of human hepatic stellate cells: a link between HIV infection and liver fibrogenesis. Gut 2010, 59(4):513-520.

48. Lin W, Tsai WL, Shao RX, Wu G, Peng LF, Barlow LL, Chung WJ, Zhang L, Zhao $H$, Jang JY, Chung RT: Hepatitis $C$ virus regulates transforming growth factor beta1 production through the generation of reactive oxygen species in a nuclear factor kappaB-dependent manner. Gastroenterology 2010, 138(7):2509-2518. 2518 e2501.

49. Lin W, Weinberg EM, Tai AW, Peng LF, Brockman MA, Kim KA, Kim SS, Borges CB, Shao RX, Chung RT: HIV increases HCV replication in a TGF-beta1-dependent manner. Gastroenterology 2008, 134(3):803-811.

50. Jang JY, Shao RX, Lin W, Weinberg E, Chung WJ, Tsai WL, Zhao H, Goto K, Zhang L, Mendez-Navarro J, Jilg N, Peng LF, Brockman MA, Chung RT: HIV infection increases HCV-induced hepatocyte apoptosis. J Hepatol 2011, 54(4):612-620. 
51. Lan L, Gorke S, Rau SJ, Zeisel MB, Hildt E, Himmelsbach K, Carvajal-Yepes M, Huber R, Wakita T, Schmitt-Graeff A, Royer C, Blum HE, Fischer R, Baumert TF: Hepatitis $C$ virus infection sensitizes human hepatocytes to TRAlL-induced apoptosis in a caspase 9-dependent manner. J Immunol 2008, 181(7):4926-4935.

52. Iser DM, Avihingsanon A, Wisedopas N, Thompson AJ, Boyd A, Matthews GV, Locarnini SA, Slavin J, Desmond PV, Lewin SR: Increased intrahepatic apoptosis but reduced immune activation in HIV-HBV co-infected patients with advanced immunosuppression. Aids 2011, 25(2):197-205.

53. Macias J, Japon MA, Saez C, Palacios RB, Mira JA, Garcia-Garcia JA, Merchante N, Vergara S, Lozano F, Gomez-Mateos J, Pineda JA: Increased hepatocyte fas expression and apoptosis in HIV and hepatitis $C$ virus coinfection. J Infect Dis 2005, 192:1566-1576.

54. Brenchley JM, Price DA, Schacker TW, Asher TE, Silvestri G, Rao S, Kazzaz Z, Bornstein E, Lambotte O, Altmann D, Blazar BR, Rodriguez B, Teixeira-Johnson L, Landay A, Martin JN, Hecht FM, Picker L, Lederman MM, Deeks SG, Douek DC: Microbial translocation is a cause of systemic immune activation in chronic HIV infection. Nat Med 2006, 12(12):1365-1371.

55. Crane M, Avihingsanon A, Rajasuriar R, Velayudham $P$, Iser D, Solomon A Sebolao B, Tran A, Spelman T, Matthews G, Cameron P, Tangkijvanich P, Dore GJ, Ruxrungtham K, Lewin SR: Lipopolysaccharide, immune activation, and liver abnormalities in HIV/hepatitis B virus (HBV)-coinfected individuals receiving $\mathrm{HBV}$-active combination antiretroviral therapy. J Infect Dis 2014 210(5):745-751.

56. Sandler NG, Koh C, Roque A, Eccleston UL, Siegel RB, Demino M, Kleiner DE, Deeks SG, Liang TJ, Heller T, Douek DC: Host response to translocated microbial products predicts outcomes of patients with HBV or HCV infection. Gastroenterology 2011, 141:1220-1230. 1230 e1221-1223.

57. Paik YH, Schwabe RF, Bataller R, Russo MP, Jobin C, Brenner DA: Toll-like receptor 4 mediates inflammatory signaling by bacterial lipopolysaccharide in human hepatic stellate cells. Hepatology 2003, 37(5):1043-1055.

58. Seki E, De Minicis S, Osterreicher CH, Kluwe J, Osawa Y, Brenner DA, Schwabe RF: TLR4 enhances TGF-beta signaling and hepatic fibrosis. Nat Med 2007, 13(11):1324-1332.

59. Crane M, Iser D, Lewin SR: Human immunodeficiency virus infection and the liver. World J Hepatol 2012, 4(3):91-98.

60. Balagopal A, Philp FH, Astemborski J, Block TM, Mehta A, Long R, Kirk GD, Mehta SH, Cox AL, Thomas DL, Ray SC: Human immunodeficiency virus-related microbial translocation and progression of hepatitis C. Gastroenterology 2008, 135:226-233.

61. French AL, Evans CT, Agniel DM, Cohen MH, Peters M, Landay AL, Desai SN: Microbial translocation and liver disease progression in women coinfected with HIV and hepatitis C virus. J Infect Dis 2013, 208(4):679-689.

62. Kovacs A, Al-Harthi L, Christensen S, Mack W, Cohen M, Landay A: CD8(+) T cell activation in women coinfected with human immunodeficiency virus type 1 and hepatitis C virus. J Infect Dis 2008, 197(10):1402-1407

63. Kovacs A, Karim R, Mack WJ, Xu J, Chen Z, Operskalski E, Frederick T, Landay A, Voris J, Spencer LS, Young MA, Tien PC, Augenbraun M, Strickler HD, Al-Harthi L: Activation of CD8 T cells predicts progression of HIV infection in women coinfected with hepatitis C virus. J Infectious Dis 2010, 201(6):823-834.

64. Cocchi F, DeVico AL, Garzino-Demo A, Arya SK, Gallo RC, Lusso P: Identification of RANTES, MIP-1 alpha, and MIP-1 beta as the major HIV-suppressive factors produced by CD8+ T cells. Science 1995, 270(5243):1811-1815.

65. Bleul CC, Farzan M, Choe H, Parolin C, Clark-Lewis I, Sodroski J, Springer TA: The lymphocyte chemoattractant SDF-1 is a ligand for LESTR/fusin and blocks HIV-1 entry. Nature 1996, 382(6594):829-833.

66. Oberlin E, Amara A, Bachelerie F, Bessia C, Virelizier JL, Arenzana-Seisdedos F, Schwartz O, Heard JM, Clark-Lewis I, Legler DF, Loetscher M, Baggiolini M, Moser B: The CXC chemokine SDF-1 is the ligand for LESTR/fusin and prevents infection by T-cell-line-adapted HIV-1. Nature 1996, 382(6594):833-835.

67. Mack M, Luckow B, Nelson PJ, Cihak J, Simmons G, Clapham PR, Signoret N, Marsh M, Stangassinger M, Borlat F, Wells TN, Schlöndorff D, Proudfoot AE: Aminooxypentane-RANTES induces CCR5 internalization but inhibits recycling: a novel inhibitory mechanism of HIV infectivity. J Exp Med 1998, 187(8):1215-1224.

68. Fätkenheuer G, Pozniak AL, Johnson MA, Plettenberg A, Staszewski S, Hoepelman Al, Saag MS, Goebel FD, Rockstroh JK, Dezube BJ, Jenkins TM, Medhurst C, Sullivan JF, Ridgway C, Abel S, James IT, Youle M, van der Ryst E: Efficacy of short-term monotherapy with maraviroc, a new CCR5 antagonist, in patients infected with HIV-1. Nat Med 2005, 11(11):1170-1172.
69. Mengozzi M, De Filippi C, Transidico P, Biswas P, Cota M, Ghezzi S, Vicenzi E, Mantovani A, Sozzani S, Poli G: Human immunodeficiency virus replication induces monocyte chemotactic protein-1 in human macrophages and U937 promonocytic cells. Blood 1999, 93(6):1851-1857.

70. Ansari AW, Bhatnagar N, Dittrich-Breiholz O, Kracht M, Schmidt RE, Heiken $\mathrm{H}$ : Host chemokine (C-C motif) ligand-2 (CCL2) is differentially regulated in HIV type 1 (HIV-1)-infected individuals. Int Immunol 2006, 18(10):1443-1451.

71. Ansari AW, Schmidt RE, Heiken H: Prednisolone mediated suppression of HIV-1 viral load strongly correlates with C-C chemokine CCL2: In vivo and in vitro findings. Clin Immunol 2007, 125(1):1-4.

72. Ansari AW, Heiken H, Meyer-Olson D, Schmidt RE: CCL2: a potential prognostic marker and target of anti-inflammatory strategy in HIV/AIDS pathogenesis. Eur J Immunol 2011, 41(12):3412-3418.

73. Cinque $P$, Vago L, Mengozzi M, Torri V, Ceresa D, Vicenzi E, Transidico P, Vagani A, Sozzani S, Mantovani A, Lazzarin A, Poli G: Elevated cerebrospinal fluid levels of monocyte chemotactic protein-1 correlate with HIV-1 encephalitis and local viral replication. Aids 1998, 12(11):1327-1332.

74. Ansari AW, Heiken H, Moenkemeyer M, Schmidt RE: Dichotomous effects of C-C chemokines in HIV-1 pathogenesis. Immunol Lett 2007, 110(1):1-5.

75. Ansari AW, Kamarulzaman A, Schmidt RE: Multifaceted Impact of Host C-C Chemokine CCL2 in the Immuno-Pathogenesis of HIV-1/M. tuberculosis Co-Infection. Front Immunol 2013, 4:312.

76. Campbell GR, Spector SA: CCL2 increases X4-tropic HIV-1 entry into resting CD4+ T cells. J Biol Chem 2008, 283(45):30745-30753.

77. Jourdan P, Abbal C, Noraz N, Hori T, Uchiyama T, Vendrell JP, Bousquet J, Taylor N, Pene J, Yssel H: IL-4 induces functional cell-surface expression of CXCR4 on human T cells. J Immunol 1998, 160(9):4153-4157.

78. Gu L, Tseng S, Horner RM, Tam C, Loda M, Rollins BJ: Control of TH2 polarization by the chemokine monocyte chemoattractant protein-1. Nature 2000, 404(6776):407-411.

79. Fantuzzi L, Spadaro F, Vallanti G, Canini I, Ramoni C, Vicenzi E, Belardelli F, Poli G, Gessani S: Endogenous CCL2 (monocyte chemotactic protein-1) modulates human immunodeficiency virus type- 1 replication and affects cytoskeleton organization in human monocyte-derived macrophages. Blood 2003, 102(7):2334-2337.

80. Sui Y, Li S, Pinson D, Adany I, Li Z, Villinger F, Narayan O, Buch S: Simian human immunodeficiency virus-associated pneumonia correlates with increased expression of MCP-1, CXCL10, and viral RNA in the lungs of rhesus macaques. Am J Pathol 2005, 166(2):355-365.

81. Toossi Z, Johnson JL, Kanost RA, Wu M, Luzze H, Peters P, Okwera A, Joloba M, Mugyenyi P, Mugerwa RD, Aung H, Ellner JJ, Hirsch CS: Increased replication of HIV-1 at sites of Mycobacterium tuberculosis infection: potential mechanisms of viral activation. J Acquir Immune Defic Syndr 2001, 28(1):1-8.

82. Capece D, Fischietti M, Verzella D, Gaggiano A, Cicciarelli G, Tessitore A, Zazzeroni F, Alesse E: The inflammatory microenvironment in hepatocellular carcinoma: a pivotal role for tumor-associated macrophages. Biomed Res Int 2013, 2013:187204.

83. Van Sweringen HL, Sakai N, Quillin RC, Bailey J, Schuster R, Blanchard J, Goetzman H, Caldwell CC, Edwards MJ, Lentsch AB: Roles of hepatocyte and myeloid CXC chemokine receptor- 2 in liver recovery and regeneration after ischemia/reperfusion in mice. Hepatology 2013, 57(1):331-338.

84. Teicher BA, Fricker SP: CXCL12 (SDF-1)/CXCR4 pathway in cancer. Clin Cancer Res 2010, 16(11):2927-2931.

85. Decalf J, Fernandes $S$, Longman $R$, Ahloulay M, Audat F, Lefrerre F, Rice CM, Pol S, Albert ML: Plasmacytoid dendritic cells initiate a complex chemokine and cytokine network and are a viable drug target in chronic HCV patients. J Exp Med 2007, 204(10):2423-2437.

86. Matsuno K, Nomiyama H, Yoneyama H, Uwatoku R: Kupffer cell-mediated recruitment of dendritic cells to the liver crucial for a host defense. Dev Immunol 2002, 9(3):143-149.

87. Asselah T, Bieche I, Laurendeau I, Paradis V, Vidaud D, Degott C, Martinot M, Bedossa $P$, Valla D, Vidaud M, Marcellin P: Liver gene expression signature of mild fibrosis in patients with chronic hepatitis C. Gastroenterology 2005, 129:2064-2075.

88. Zhdanov KV, Gusev DA, Chirskii VS, Sysoev KA, lakubovskaia LA, Shakhmanov DM, Totolian AA: Chronic HCV-infection and expression of mRNA of CC-chemokines and their receptors]. Zh Mikrobiol Epidemiol Immunobiol 2008, 4:73-78.

89. Neuman MG, Benhamou JP, Marcellin P, Valla D, Malkiewicz IM, Katz GG, Trepo C, Bourliere M, Cameron RG, Cohen L, Morgan M, Schmilovitz-Weiss H, 
Ben-Ari Z: Cytokine-chemokine and apoptotic signatures in patients with hepatitis C. Transl Res 2007, 149(3):126-136.

90. Micheloud D, Salcedo M, Banares R, Rincon D, Lorente R, Munoz-Fernandez MA, Resino S: Serum levels of fibrosis biomarkers measured early after liver transplantation are associated with severe hepatitis $C$ virus recurrence. Transpl Infect Dis 2009, 11(2):183-188.

91. Yu DC, Chen J, Sun XT, Zhuang LY, Jiang CP, Ding YT: Mechanism of endothelial progenitor cell recruitment into neo-vessels in adjacent non-tumor tissues in hepatocellular carcinoma. BMC Cancer 2010, 10:435.

92. Friedman BH, Wolf JH, Wang L, Putt ME, Shaked A, Christie JD, Hancock WW, Olthoff KM: Serum cytokine profiles associated with early allograft dysfunction in patients undergoing liver transplantation. Liver Transp/ 2012, 18(2):166-176.

93. Nishitsuji H, Funami K, Shimizu Y, Ujino S, Sugiyama K, Seya T, Takaku H, Shimotohno K: Hepatitis C virus infection induces inflammatory cytokines and chemokines mediated by the cross talk between hepatocytes and stellate cells. J Virol 2013, 87(14):8169-8178.

94. Bataller R, Brenner DA: Liver fibrosis. J Clin Invest 2005, 115(2):209-218.

95. Friedman SL: Hepatic stellate cells: protean, multifunctional, and enigmatic cells of the liver. Physiol Rev 2008, 88(1):125-172.

96. Seki E, de Minicis S, Inokuchi S, Taura K, Miyai K, van Rooijen N, Schwabe RF, Brenner DA: CCR2 promotes hepatic fibrosis in mice. Hepatology 2009, 50(1):185-197.

97. Harada K, Chiba M, Okamura A, Hsu M, Sato Y, Igarashi S, Ren XS, Ikeda H, Ohta H, Kasashima S, Kawashima A, Nakanuma Y: Monocyte chemoattractant protein-1 derived from biliary innate immunity contributes to hepatic fibrogenesis. J Clin Pathol 2011, 64(8):660-665.

98. Korenaga M, Wang T, Li Y, Showalter LA, Chan T, Sun J, Weinman SA: Hepatitis $C$ virus core protein inhibits mitochondrial electron transport and increases reactive oxygen species (ROS) production. J Biol Chem 2005, 280(45):37481-37488.

99. Muhlbauer M, Bosserhoff AK, Hartmann A, Thasler WE, Weiss TS, Herfarth H, Lock G, Scholmerich J, Hellerbrand C: A novel MCP-1 gene polymorphism is associated with hepatic MCP-1 expression and severity of HCV-related liver disease. Gastroenterology 2003, 125(4):1085-1093.

100. Rockstroh JK, Bhagani S: Managing HIV/hepatitis C co-infection in the era of direct acting antivirals. BMC Med 2013, 11:234.

101. Grint D, Peters L, Schwarze-Zander C, Beniowski M, Pradier C, Battegay M, Jevtovic D, Soriano V, Lundgren JD, Rockstroh JK, Kirk O, Mocroft A, EuroSIDA in EuroCoord: Temporal changes and regional differences in treatment uptake of hepatitis C therapy in EuroSIDA. HIV Med 2013, 14(10):614-623.

102. Sulkowski M, Pol S, Mallolas J, Fainboim H, Cooper C, Slim J, Rivero A, Mak C, Thompson S, Howe AY, Wenning L, Sklar P, Wahl J, Greaves W: P05411 study investigators: Boceprevir versus placebo with pegylated interferon alfa- $2 b$ and ribavirin for treatment of hepatitis $C$ virus genotype 1 in patients with HIV: a randomised, double-blind, controlled phase 2 trial. Lancet Infect Dis 2013, 13(7):597-605.

103. Sulkowski MS, Sherman KE, Dieterich DT, Bsharat M, Mahnke L, Rockstroh JK, Gharakhanian S, McCallister S, Henshaw J, Girard PM, Adiwijaya B, Garg V, Rubin RA, Adda N, Soriano V: Combination therapy with telaprevir for chronic hepatitis C virus genotype 1 infection in patients with HIV: a randomized trial. Ann Intern Med 2013, 159(2):86-96.

\section{doi:10.1186/s12967-014-0341-8}

Cite this article as: Ansari et al: Immuno-pathomechanism of liver fibrosis: targeting chemokine CCL2-mediated HIV:HCV nexus. Journal of Translational Medicine 2014 12:341.

\section{Submit your next manuscript to BioMed Central and take full advantage of:}

- Convenient online submission

- Thorough peer review

- No space constraints or color figure charges

- Immediate publication on acceptance

- Inclusion in PubMed, CAS, Scopus and Google Scholar

- Research which is freely available for redistribution

Submit your manuscript at www.biomedcentral.com/submit 